\title{
Analysis Strategic of Improvement through economic Fishermen'Coastal Communities in Pahlawan Village, Tanjung Tiram Sub-District, Batu Bara Regency
}

\author{
Annisa Ilmi Faried ${ }^{1}$ and Diwayana Putri Nasution ${ }^{1}$ \\ \{ annisailmi@dosen.pancabudi.ac.id ${ }^{1}$,diwayanaputri@dosen.pancabudi.ac.id ${ }^{2}$ \} \\ ${ }^{1}$ Universitas Pembangunan Panca Budi Medan, Jl. Gatot Subroto Km. 4,5 Medan, Indonesia
}

\begin{abstract}
The Government has an essential role in every program created to improve the welfare of coastal communities. The effort to improve coastal development has slightly overcome the government's strategy in tackling the well-being of coastal communities. The government's current plan of Hierarchy Process Analysis (AHP) includes government policies, service quality, capital access development, school facilities development, access to fishery resources, skills development, and technological mastery. CFA Test: From the KMO and Bartlett's Test table, we get the value of Kaiser Mayer Olkin (KMO) of 0.547 where the cost is higher than 0.5 . This value indicates that the data is valid for further analysis with Factor analysis. Bartlet test value of 53.965 with a significant amount of 0.002 far below $5 \%$, then the correlation matrix formed is the identity matrix. The method in this research is using CFA (Confirmatory Factor Analysis) to choose which variable affect the dependent variable and multiple regression analysis methods which aim to analyze the influence of independent variable to dependent variable separately or together.
\end{abstract}

Keyword: Welfare of fishermen, economic empowerment, CFA, AHP

\section{Introduction}

One of the new trends in the paradigm of development throughout the region in Indonesia today is associated with improving the welfare of coastal communities. To be able to advance the well-being and independence of a part in a sustainable development process that can improve human resources, quality, and social systems or social institutions.

The condition of the population in the coastal area found in the Pahlawan Village of Batu Bara type of livelihood is dominated by the fishery sector which is closely related to the availability of the primary natural resources utilized, i.e., coastal and marine resources.

The Government has a vital role in every program created to improve the welfare of coastal communities. The government's strategy in tackling the health of coastal communities becomes a bit overcome to increase coastal development. The government's current plan is Hierarchical Process Analysis (AHP) that includes government policy, service quality, capital access development, school facility development, infrastructure and facilities development, fishery resource access, skills development, and technical mastery. With the development strategy of coastal development is expected to be a solution where the completion needs to be done through a comprehensive plan by placing socio-economic and cultural values that have been embedded within the community as a factor driving change. 
Table 1. Plenty of Family by Level of Welfare Each District in Batu Bara Regency

\begin{tabular}{llllll}
\hline \multirow{2}{*}{ Districts } & \multicolumn{5}{c}{ Prosperity Level } \\
\cline { 2 - 6 } & Pra-S & KS-I & KS-II & KS-III & KS-III Plus \\
\hline Sei Balai & 315 & 1.558 & 3.111 & 1.348 & 1.497 \\
\hline Tanjung Tiram & 3.566 & 4.221 & 9.145 & 413 & - \\
\hline Talawi & 373 & 3.136 & 3.696 & 4.962 & 2.993 \\
\hline Lima Puluh & 2.913 & 3.357 & 7.491 & 6.714 & 2.549 \\
\hline Air Putih & 1.536 & 2.545 & 4.306 & 3.989 & 368 \\
\hline Sei Suka & 251 & 402 & 609 & 8.989 & 3.311 \\
\hline Medang Deras & 1.363 & 4.877 & 4.877 & 3.801 & 900 \\
\hline Batu Bara & 10.317 & 17.311 & 33.235 & 30.216 & 11.618 \\
\hline
\end{tabular}

Source: Women and Family Planning Board of Batu Bara Regency, the Year 2017

From the above data, it is known that the highest number of pre prosperous families are in Tanjung Tiram sub-district, where Tanjung Tiram sub-district is the closest to the sea compared to other areas in Batubara District. Pahlawan village located in the District of Tanjung Tiram is the village closest to the sea or commonly called coastal regions. The low level of the welfare of the hero community is one of the reasons for the lack of development of the coastal areas where the government policy that has not yet touched the coastal city of Pahlawan Village as in the case of public service, capital, facilities and infrastructure issues and so forth.

Strategic Analysis of Fishermen's Welfare Improvement through Economic Empowerment of Coastal Communities In Pahlawan Village, Tanjung Tiram Sub-district, Batu Bara Regency is critical to do, where the government is currently promoting coastal development, so this research can be a benchmark of government's success in carrying out various development strategies the coastal region. Besides coastal development that aims to improve the welfare of coastal communities or the health of fishers is a thing that is highly anticipated by coastal communities considering the welfare level of coastal anglers are generally low and especially in the village of Hero is very low.

The results of this study is expected to be an input for the government in assessing the success of strategies to improve the welfare of the coastal community that is being done, for the fishermen are expected to open the mind and add insight to become more qualified human and able to explore the potentials of human resources and natural resources the village and make it an economic value that must be supported from the government.

This study described a government policy, community empowerment, development of access to capital, construction of school facilities, the building of facilities and infrastructure, access to fish resources, skills, and use of coastal community technology.

\section{Literature Review}

Coastal communities can be illustrated as groups of people living in coastal areas and have a source of economic life that depends directly on the utilization of marine and coastal resources. They consist of fisherman owners, fishermen laborers, fish farmers and other marine organisms, fish traders, fish processors, as well as suppliers of input production facilities. Coastal area is a landing place of fish as well as various marine resources and other resource flows to then flowed to the mainland. Measurement of family or household welfare becomes more complex, because the family consists of individuals who live together and interact to achieve the same goals of family welfare. Various indicators or measurements of 
family welfare have been used, however, there is no appropriate or ideal measure to measure family welfare. Muflikhati 2010 stated that the results of the analysis conducted by Martinez el al (2003) show in general that family welfare is described with regard to health aspects, economic factors, healthy family life, education, community life and community support and diversity and culture. According to BPS, in 2015, public welfare indicators are published, consisting of various aspects, namely education, health and nutrition, population, employment, level and consumption and other social aspects. In this publication only presented various conditions related to the six aspects but there is no specific number to measure welfare in general. In these people's welfare indiactors can be distinguished between the region or province but not in the household.

\section{Methodology}

The material that will be used in this research is related to fisherman's improvement strategy covering government policy (X1), community empowerment (X2), development of capital access (X3), construction of school facilities (X4), development of facilities and infrastructure (X5) access to fish resources (X6), skills development (X7), use of technology (X8) and community economic empowerment (Y) in Pahlawan Village, Tanjung Tiram District, Batu Bara Regency. Quantitative analysis in this study is to predict and control a symptom on the strategy to improve the welfare of fishers through economic empowerment of coastal communities in the Village District Pahlawan Tanjung Tiram Batu Bara. Confirmatory Factor Analysis (CFA), Confirmatory Factor Analysis aims to find a way to summarize the information in the original variable into a set of new dimensions or variate with the formula:

$\mathrm{Xi}=\mathrm{Bi} 1 \mathrm{~F} 1+\mathrm{Bi} 2 \mathrm{~F} 2+\mathrm{Bi} 3 \mathrm{~F} 3+\ldots .+\mathrm{Vi} \mu \mathrm{i}$

wheres:

$\mathrm{Xi}=$ The standard $\mathrm{i}$-th variable

$\mathrm{Bij}=$ Partial regression coefficient which for variable $\mathrm{i}$ in the common factor $\mathrm{j}$

$\mathrm{Fj}=$ Common factor $\mathrm{i}$-th

$\mathrm{Vi}=$ The standardized regression coefficient for the $\mathrm{i}$-th variable on the $\mathrm{i}$-th unique factor

$\mu \mathrm{i}=$ The unique factor of the $\mathrm{i}$-th variable

Testing criteria: factor is expressed as a dominant factor if have a coefficient of matrix component $>0,5$. Specifically for Factor Analysis, the following assumptions must be met: (Santoso, 2006).

- Correlation between Independent variables. The association or correlation between independent variables should be strong enough, e.g., above 0.5 .

- Partial Correlation. Partial correlation of incomplete, the relationship between two variables by assuming fixed other variable, it must be small. In SPSS detection of partial correlation is given via Anti-Image Correlation option.

- Testing all correlation matrix (the relationship between variables), as measured by the Bartlett Test of Sphericity or Measure Sampling Adequacy (MSA). This test requires a significant correlation between at least a few variables.

- In some cases, the assumption of Normality of the variables or factors that occur should be met.

\section{Results And Discussion}

To analyze the data of research, the researcher performs and applies descriptive analysis technique that is by examining and grouping, then interpreted so that will get the real picture 
about the problem under study. Furthermore, factor analysis was conducted to find a way to summarize the information in the original variable into a set of new dimensions or variables (factors). Data processing using the SPSS program, with the following results:

Tables 2. KMO and Bartlett's Test

\begin{tabular}{lll}
\hline \multicolumn{2}{l}{ Kaiser-Meyer-Olkin Measure of sampling Adequecy } & .547 \\
\hline Bartlett's Test of Sphericity & Approx. Chi-Squere & 53.965 \\
\hline & DF & 28 \\
\hline Sig. & .002 \\
\hline
\end{tabular}

Furthermore, to see which variables have the value of communalities corelation above or below 0.5 or above $50 \%$ can be seen in the following table comunalities

Tabel 3. Communalities

\begin{tabular}{lll}
\hline & Initial & Extraction \\
\hline Government Policy & 1.000 & .444 \\
\hline Service Quality & 1.000 & .723 \\
\hline Development of Capital Acces & 1.000 & .537 \\
\hline Construction of School Facilities & 1.000 & .578 \\
\hline Development of Facilities and Infrastructure & 1.000 & .561 \\
\hline Access of Fish Resources & 1.000 & .494 \\
\hline Skills Development & 1.000 & .722 \\
\hline Use of Technology & 1.000 & .550 \\
\hline
\end{tabular}

Extraction Method: Principal Component Analysis

Tables 4. Total Variance Explained

\begin{tabular}{|c|c|c|c|c|c|c|c|c|c|}
\hline & \multicolumn{3}{|c|}{ Initial Eigenvalues } & \multicolumn{3}{|c|}{$\begin{array}{l}\text { Extraction Sums of } \\
\text { Sequared Loadings }\end{array}$} & \multicolumn{3}{|c|}{$\begin{array}{l}\text { Rotation Sums of Sequared } \\
\text { Loadings }\end{array}$} \\
\hline & $\begin{array}{l}\text { Tota } \\
1\end{array}$ & $\begin{array}{l}\% \text { of } \\
\text { Varian } \\
\text { ce }\end{array}$ & $\begin{array}{l}\text { Cumulativ } \\
\text { es } \%\end{array}$ & $\begin{array}{l}\text { Tota } \\
1\end{array}$ & $\begin{array}{l}\% \text { of } \\
\text { Varian } \\
\text { ce }\end{array}$ & $\begin{array}{l}\text { Cumulativ } \\
\text { es } \%\end{array}$ & $\begin{array}{l}\text { Tota } \\
1\end{array}$ & $\begin{array}{l}\% \text { of } \\
\text { Varian } \\
\text { ce }\end{array}$ & $\begin{array}{l}\text { Cumulativ } \\
\text { es } \%\end{array}$ \\
\hline 1 & $\begin{array}{l}1.88 \\
1\end{array}$ & 23.513 & 23.513 & $\begin{array}{l}1.88 \\
1\end{array}$ & 23.513 & 23.513 & $\begin{array}{l}1.59 \\
7\end{array}$ & 19.966 & 19.966 \\
\hline 2 & $\begin{array}{l}1.52 \\
0\end{array}$ & 18.998 & 42.511 & $\begin{array}{l}1.52 \\
0\end{array}$ & 18.998 & 42.511 & $\begin{array}{l}1.58 \\
2\end{array}$ & 19.775 & 39.741 \\
\hline 3 & $\begin{array}{l}1.20 \\
8\end{array}$ & 57.615 & 57.615 & $\begin{array}{l}1.20 \\
8 \\
\end{array}$ & 15.104 & 57.615 & $\begin{array}{l}1.43 \\
0\end{array}$ & 17.874 & 57.615 \\
\hline 4 & .976 & 12.202 & 69.817 & & & & & & \\
\hline 5 & .766 & 9.579 & 79.396 & & & & & & \\
\hline 6 & .653 & 8.164 & 87.560 & & & & & & \\
\hline 7 & .533 & 6.657 & 94.217 & & & & & & \\
\hline 8 & .463 & 5.783 & 100.000 & & & & & & \\
\hline
\end{tabular}

Based on a result of the total variance explained in the initial Eigenvalues table, it known that there are only three components of the variable that become the factors influencing the economic empowerment of society. Eigenvalues showed the relative importance of each 
element in calculating the eight variances of the variables analyzed. From the table above shows that there are only three factors that formed. Since the three factors have a total value of eigenvalues above 1, that is, 1.881 for factor $1,1,520$ for factor 2 and 1,208 for consideration three so that the factoring process stops at the three elements that will follow in the next analysis.

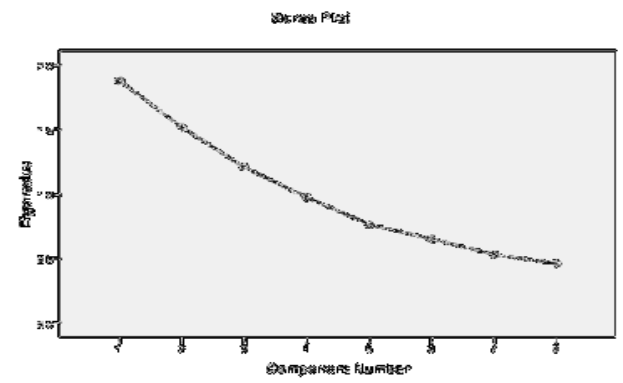

Fig. 1. Scree plot Component Number

The screen plot graph shows that from one to two factors (the line from the Component Number axis $=1$ to 2 ), the direction of the chart decreases. Then from number 2 to 3 , the line still decreases. While the number 3 to number, four is below the number 1 of the Y-axis (Eigenvalues). This suggests that three factors are best for summarizing the eight variables.

Tables 5. Component Matrix ${ }^{\mathrm{a}}$

\begin{tabular}{lccc}
\hline & \multicolumn{3}{c}{ Component } \\
\cline { 2 - 4 } & 1 & 2 & 3 \\
\hline Government Policy & .350 & .304 & .478 \\
\hline Service Quality & -.522 & .448 & -.461 \\
\hline Development of Capital Acces & .574 & .448 & .080 \\
\hline Construction of School Facilities & .669 & -.187 & -.308 \\
\hline Development of Facilities and Infrastructure & -.593 & -.057 & .454 \\
\hline Access of Fish Resources & -.387 & .411 & .419 \\
\hline Skills Development & .348 & .770 & .088 \\
\hline Use of Technology & -.291 & .435 & -.526 \\
\hline
\end{tabular}

\section{a. 3 components extracted}

Having known that the three factors are the most optimal number, it can be seen in the Component Matrix table shows the distribution of the eight variables on three elements formed. While the figures in the table are factor loadings, which shows the correlation between a variable with factor 1 , component 2 , and factor 3 . The process of determining which variables will go into which consideration, done by making an extensive comparison of correlation on each line.

The component matrix table shows a correlation above 0.5. in factor 1 is the development of capital access and construction of school facilities. In element 2 is skill development variable. While on component 3 there is no correlation above 0.5 . Next to the process of Rotation factor or rotation of the factors formed. The purpose of rotation to clarify the variables that go into individual elements. 
Tables 6 . Rotated Component Matrix ${ }^{\mathrm{a}}$

\begin{tabular}{llcc}
\hline & \multicolumn{3}{c}{ Component } \\
\cline { 2 - 4 } & 1 & 2 & 3 \\
\hline Government Policy & .575 & .129 & -.311 \\
\hline Service Quality & -.044 & .207 & .823 \\
\hline Development of Capital Acces & .687 & -.252 & -.044 \\
\hline Construction of School Facilities & .123 & -.730 & -.173 \\
\hline Development of Facilities and Infrastructure & -.227 & .707 & -.101 \\
\hline Access of Fish Resources & .239 & .653 & .103 \\
\hline Skills Development & .818 & -.002 & .230 \\
\hline Use of Technology & -.020 & -.016 & .741 \\
\hline
\end{tabular}

Extraction Method: Principal Component Analysis

Rotation Method: Varimax with Kaiser Normalization

a.Rotation converged in 5 iterations

Rotated Component Matrix (Rotated Component Matrix) shows a more precise and more public distribution of a variable. It appears that the small loading factor is getting smaller and the significant loading factor is getting bigger.

Based on the results of the matrix component values it is known that of the eight factors, then it is reasonable to affect the family income are three factors that come from:

- The 1st largest component: Skills Development

- The 2nd largest segment: Construction of Facilities and Infrastructure

- The 3rd largest segment: Quality of ServiceRotated Component Matrix (Rotated Component Matrix) shows a more precise and more public distribution of a variable. It appears that the small loading factor is getting smaller and the significant loading factor is getting bigger.

Based on the results of the matrix component values it is known that of the eight factors, then it is reasonable to affect the family income are three factors that come from:

- The 1st largest component: Skills Development

- The 2nd largest segment: Construction of Facilities and Infrastructure

- The 3rd most significant part: Quality of Service

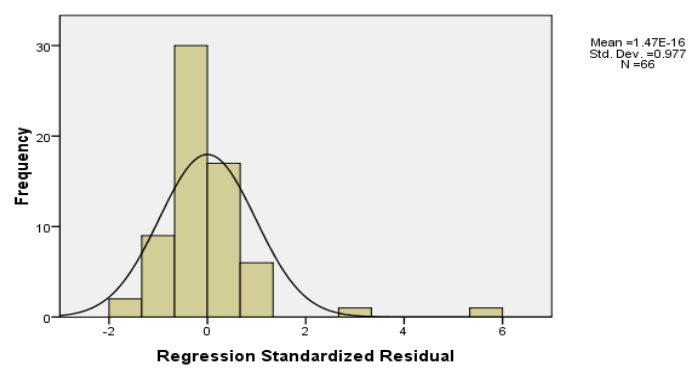

Fig. 2. Histogram Regression Standardized Residual 


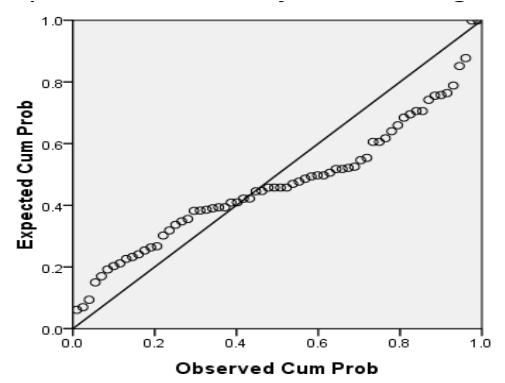

Multikolinieritas

Fig. 2. observed cum prob

Tables 7. Coefficients ${ }^{\mathrm{a}}$

\begin{tabular}{|c|c|c|c|c|c|c|c|c|c|c|}
\hline \multirow[t]{2}{*}{ Modal } & \multicolumn{2}{|c|}{$\begin{array}{l}\text { Unstandardized } \\
\text { coefficients }\end{array}$} & \multirow{2}{*}{$\begin{array}{c}\text { Standardi } \\
\text { zed } \\
\text { coefficien } \\
\text { ts }\end{array}$} & \multirow[t]{2}{*}{$\mathrm{T}$} & \multirow{2}{*}{$\begin{array}{c}\text { Sig } \\
\cdot \\
\end{array}$} & \multicolumn{3}{|c|}{ Correlations } & \multicolumn{2}{|c|}{$\begin{array}{l}\text { Collinearity } \\
\text { Statistics }\end{array}$} \\
\hline & B & $\begin{array}{l}\text { Std.Er } \\
\text { ror }\end{array}$ & & & & $\begin{array}{c}\text { Zer } \\
\text { o- } \\
\text { Ord } \\
\text { er }\end{array}$ & $\begin{array}{c}\text { Parti } \\
\text { al }\end{array}$ & $\begin{array}{c}\text { Par } \\
\mathrm{t}\end{array}$ & $\begin{array}{c}\text { Tolera } \\
\text { nce }\end{array}$ & VIF \\
\hline 1(constant & $\begin{array}{l}- \\
1062.6 \\
02\end{array}$ & $\begin{array}{l}741.12 \\
1\end{array}$ & & $\begin{array}{l}- \\
1.4 \\
34 \\
\end{array}$ & $\begin{array}{l}.15 \\
7\end{array}$ & & & & & \\
\hline $\begin{array}{l}\text { Penge,ban } \\
\text { gan } \\
\text { Keterampi } \\
\text { lan }\end{array}$ & $\begin{array}{l}1165.5 \\
30\end{array}$ & $\begin{array}{l}229.11 \\
8\end{array}$ & .513 & $\begin{array}{l}5.0 \\
87\end{array}$ & $\begin{array}{l}.00 \\
0\end{array}$ & .559 & .543 & $\begin{array}{l}.50 \\
2\end{array}$ & .958 & $\begin{array}{l}1.0 \\
44\end{array}$ \\
\hline $\begin{array}{l}\text { Pembangu } \\
\text { nan } \\
\text { Sarana \& } \\
\text { Prasarana }\end{array}$ & $\begin{array}{l}769.39 \\
8\end{array}$ & $\begin{array}{l}262.28 \\
5\end{array}$ & .293 & $\begin{array}{l}2.9 \\
33\end{array}$ & $\begin{array}{l}.00 \\
5\end{array}$ & .380 & .349 & $\begin{array}{l}.28 \\
9\end{array}$ & .971 & $\begin{array}{l}1.0 \\
29\end{array}$ \\
\hline $\begin{array}{l}\text { Kualitas } \\
\text { Pelayanan }\end{array}$ & $\begin{array}{l}- \\
65.162\end{array}$ & $\begin{array}{l}283.45 \\
5\end{array}$ & -.023 & - & $\begin{array}{l}.81 \\
9\end{array}$ & .043 & $\begin{array}{l}- \\
.029\end{array}$ & $\begin{array}{l}- \\
.02 \\
3\end{array}$ & .986 & $\begin{array}{l}1.0 \\
15\end{array}$ \\
\hline
\end{tabular}

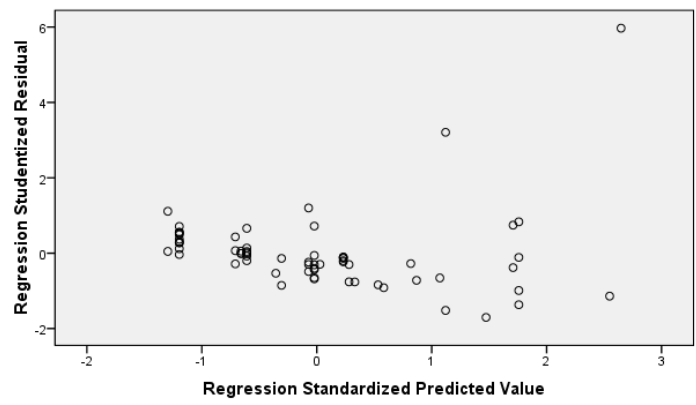

Fig. 4. Scatterplot economic 


\section{Conclusions}

Based on the results of the research above that fishermen community characteristics can merely be described as fishing communities have distinctive features that are different from other cities, such as

- Fishermen community has a homogeneous character regarding livelihood, values, and culture and in attitude and behavior,

- Society has a high tolerance to fellow family members and others,

- Have a hard personality,

- In speaking, the voice tends to increase,

- Having a very high sexual arousal, this can be seen from the number of children in one (1) family who have less than six children and is still considered little when compared with the number of children born by a couple who have children over 12 (two twelve) persons or more. Because for them many children a lot of sustenance,

- Education of coastal communities, in general, is still relatively low; this can be proven by the number of children who dropped out of school only to grade 3 elementary school or elementary school.

The CFA result analysis shows that from KMO and Bartlett's Test table, we get the value of Kaiser Mayer Olkin (KMO) of 0.547 where the cost is higher than 0.5. This value indicates that the data is valid for further analysis with Factor analysis. Bartlet test value of 53.965 with a significant amount of 0.002 below $5 \%$, then the correlation matrix formed is the identity matrix, or in other words, the factor model used is excellent. Furthermore, to see which variables have the value of communalities correlation correlation above or below 0.5 or above $50 \%$ can be seen in the table communalities show the results of individual extraction there are six variables that have a contribution that exceeds 0.5 or $50 \%$ of service quality, development of capital access, school facilitation, facility and infrastructure development, skill development, and technology usage while government policy variables and access of fish resources have extraction value below 0.5 or $50 \%$. However, the next election should be tested with Explained variance. The result of the total variation explained in the initial Eigenvalues table; it is known that there are only three components of the variable that become the factors influencing the economic empowerment of society. Eigenvalues showed the relative importance of each element in calculating the eight variances of the variables analyzed. From the table above shows that there are only three factors that are formed. Since the three components have a total value of eigenvalues above 1 , that is, 1.881 for factor $1,1,520$ for factor 2 and 1,208 for consideration three so that the factoring process stops at the three elements that will follow in the next analysis.

\section{References}

[1] Basuki, R, Prayogo U.H., Tri Pranaji, NyakIlham, Sugianto, Hendiarto, Bambang W, Daeng H., dan Iwan S,. 2001. General Guidelines For Fishermen's exchange rates.rate General of Coastal and Small Island. The Directorate General of Coastal And Small Island. DKP.Jakarta.

[2] Fauzi, Akhmad. Anna, Suzy. 2005. Fisheries and marine resource modeling for policy analysis. Jakarta: Gramedia

[3] Kristianti, Kusai, dan Bathara L. 2014. The Strategy of Survival of Labor Fishermen in Meskom Village, Bengkalis Subdistri. Bengkalis Regency, Riau Periodic Province, Terubuk Fisheries. 
